\title{
Architecture
}

\section{NEW JEWISH STYLE IN LVIV ARCHITECTURE: THE HISTORIC TRANSFORMATION IN THE URBAN SPACE}

\author{
Yuri Biryulov \\ Lviv National Academy of Arts \\ Kubiyovycha st., 38, Lviv, Ukraine \\ E-mail: yurij.biryulov@gmail.com
}

\begin{abstract}
Introduction: The phenomenon of expressing national identity in architecture is manifested in many countries and cities. In this article, it is considered in the context of Lviv with the main focus on Jewish architects. Purpose of the study: We are planning to study the process of the emergence of a new Jewish style in the architecture of Lviv from the mid-19 ${ }^{\text {th }}$ century to the first decades of the $20^{\text {th }}$ century in the context of urban development, and consider the formation of a characteristic art language, together with the corresponding symbolic elements of décor. Methods: We use a comprehensive art approach, which involves the method of systematization for material processing, comparison and synthesis. In the course of the study, we applied comparative analysis, as well as elements of systematic analysis of the Jewish architecture evolution. Results and discussion: We conclude that the architects used several strategies and theories to express Jewish cultural identity in their works, in particular, neo-romantic transformations of medieval, Renaissance and Oriental architecture, rethinking in the spirit of Art Nouveau of the Neo-Moorish style, incorporation of old regional architecture motifs, applying decor saturated with Jewish symbols.
\end{abstract}

\section{Keywords}

Lviv, Jewish architects, urban evolution, cultural identity, new national Jewish style.

\section{Introduction}

Currently, the issues of cultural globalization, and, on the contrary, the issues of identity and national styles in architecture are among the most frequently discussed in the artistic environment (Abel, 1997; Lefaivre and Tzonis, 2003; Watson and Bentley, 2007). This also applies to the issue of Jewish cultural identity and specific Jewish art style (Aleksandrowicz-Pędich and Pakier, 2012; Bedoir, 2004; Coenen Snyder, 2013; Holzer, 1999; Klein, 2005-2007; Rabin, 1996; Sachs and Van Voolen, 2004; Shapira, 2016). To what extent one can classify a piece of architecture as "Jewish" is still open to debate.

All over Europe, as well as in Lviv, these issues became relevant as early as in the middle of the 19th century, and at the turn of the $19^{\text {th }}$ and $20^{\text {th }}$ centuries, they were a matter of great concern to Jewish artists.

The historical, political, economic, and sociocultural environment was such that Lviv developed as a unique city, with an architectural stratigraphy, which can clearly reveal various stylistic blocks. However, since the mid-19 ${ }^{\text {th }}$ century, there was a search for a special, national Jewish style, especially in religious buildings. Due to the fact that the historical research of architecture in the Lviv region was unsystematic, it is not a surprise that a comprehensive view of the Jewish architecture evolution has not been formed. To resolve issues related to the study and protection of these monuments, it is essential to reveal particular patterns in the formation of Jewish architecture.

\section{Methods}

Due to the method of aesthetic and critical analysis of the art, we show some peculiarities of the formal structure of buildings, interaction between the means of artistic expression and the conceptual system of some architects. We reveal and compare the historical levels in the development of the works, their technological and stylistic changes in time, and study the relationships between various artistic techniques and plastic modeling options at different stages of architectural forms' creation. Throughout the study, we use multiple resources: theoretical works of architectural scholars; information in local newspapers in addition to archival documents. 


\section{Results and discussion \\ 1. In the Habsburg Empire: the beginning of the search for a national style}

Since the mid- $19^{\text {th }}$ century, after the revolutionary events in 1848 (Spring of Nations), historicism began to develop actively in Jewish architecture in Lviv as a complex of different retrospective trends, i.e. "neo-styles" (Revival architectural styles) (Van Pelt and Westfall, 1991). For the Jewish elite of the city, it was especially important to emphasize that the synagogues should occupy an honorary place in the city center and be built in the latest fashion blending well with the new architectural style of the city. Adapting the latest architectural styles to the needs of the community, the Jews seemed to show their readiness for full emancipation.

For instance, in 1856, the old building of the Sykstuska Synagogue was demolished and rebuilt in 1857-1859, together with the Beth Hamidrash, with features of Rundbogenstil and Romanesque Revival styles, to a design by Wilhelm Schmidt, and in 1864-1867, architect Emanuel Gall added a single-story northern wing to the Beth Hamidrash) (Fig. 1).

The façade of the Beth Hamidrash in the Romanesque Revival style acquired large arched windows, with reliefs depicting the Tablets of Stone of Moses, placed in between them at the level of the second floor. In 1876, architect Josef Engel Senior developed a design of a women's mikveh at the Sykstuska Synagogue, located at 22 Sykstuska Street (Fig. 2).

For the first time in Lviv, distinctive Moorish motifs were used in the decoration of the façade, windows and doors (State Archives of the Lviv Region, Collection 2, Register 1, File 313, pp. 22, 36-42, 96-98, 122-123, 144-155; File 3018, p. 29). This new Orientalism indicated the readiness of the then Jewish community to engage in an open inter-confessional dialogue, and explore a new synthesis of Jewish culture with the surrounding

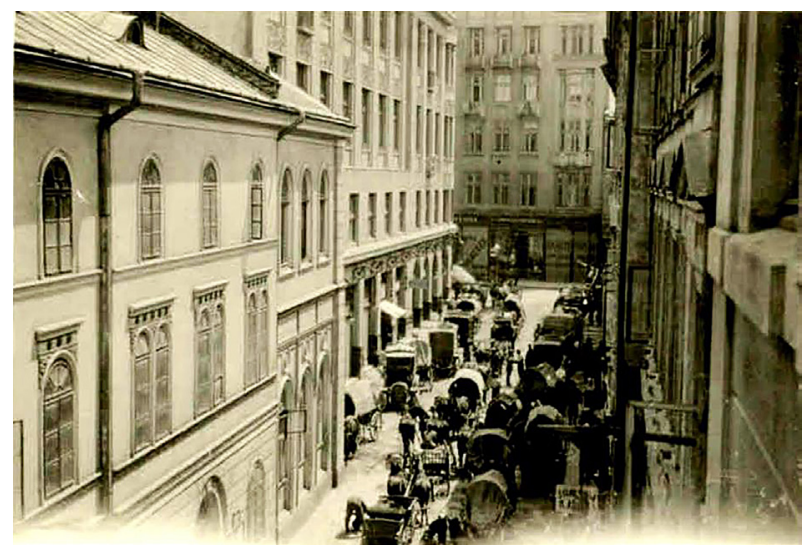

Figure 1. Sykstuska Synagogue. 1857-1867. Photo of 1916. Austrian State Archives, Vienna
Christianity. The impetus for the development of the transformed Moorish Revival style in the Jewish architecture of Lviv was brought about by the villa of Louis Pereira-Arnstein, built by Ludwig Förster in Königstetten (1849), and synagogues of his creation built in 1854-1859 in Budapest (Dohány Street) and Vienna (Leopoldstädter Tempel, destroyed in 1938) (Kalmar, 2001; Klein, 2006; Kravtsov, 2016a).

\section{Construction boom and national revival}

After the final lifting of restrictions on education, business, accommodation, and real estate purchasing in 1867, the number of Jews in Lviv increased significantly. They settled in almost every area of Lviv. During the Historicism period, an increase in the Jewish population in the city led to very intensive development in housing construction of various types of buildings. These were commissioned by members of the new Jewish elite (Buszko, 1999; Holzer, 1999).

The architecture of such villas and mansions, built for Jewish owners since the late $19^{\text {th }}$ century, amazes with the dynamics of shapes and a wide range of design, composition, and stylistic solutions. Even with such diversity, it is, nevertheless, possible to identify common specific design principles based on rationalism and convenience, which were not tarnished by non-standard plans. Since after 1867 Jews were allowed to own land, the nouveaux riches began to invest in residential tenement houses. They were actively constructed in the 1870-1890s, often forming street ensembles. In terms of style, various Neo-Renaissance interpretations dominated: Italian, French, and sometimes German NeoRenaissance. In the late 1880s, Neo-Renaissance motifs began to be increasingly linked to NeoBaroque, and eventually, in the 1890s, the latter became the absolute dominant style in housing. At the same time, symbols related to Jewish history and tradition were introduced into the decor of the facades of buildings in common European neo-styles.

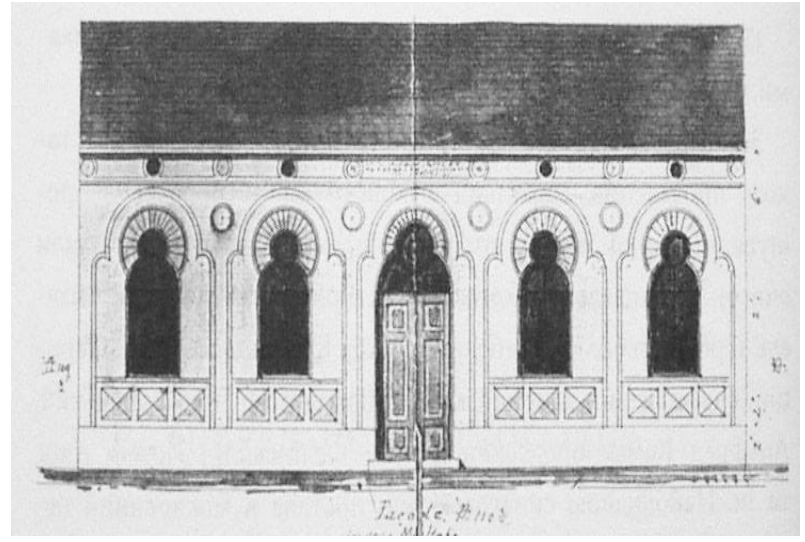

Figure 2. Design of a women's mikveh at the Sykstuska Synagogue. 1876. State Archives of the Lviv Region 
At the turn of the $19^{\text {th }}$ and $20^{\text {th }}$ centuries, the streets leading to the railway station underwent the most active development, especially Gródecka (Horodots'ka) Street and its side streets, with a new commercial area being developed around them. A large number of Jewish families settled in this district, following which synagogues were built in the Rundbogenstil and Moorish Revival style. The first of them, emerging around 1882-1890, was the synagogue of the Agudas Achim (Association of Brothers) Society at $15 \mathrm{~J}$. Bem (today's Yaroslav Mudry) Street; it was housed in a residential building built by Jan Karasiński in 1882. The Agudas Schloma (Solomon's Association) synagogue appeared at $39 \mathrm{~J}$. Bem in 1899-1902, built to a design by architect Salomon Riemer (State Archives of the Lviv Region, Collection 2, Register 3, File 1479, pp. 3, 4, 79). In 1901, the Gall-Eid (Wheel of Testimony) synagogue was built at 14 Queen Jadwiga (today's Marko Vovchok Street) at the expense of Jakob Gall and presumably to a design by Maurycy Gall. It was erected in honor of Emanuel Gall, an architect and Commander of the Jewish Guard in the Academic Legion in Lviv during the Spring of Nations in 1848, not only named after him but also including a direct reference to the Book of Genesis (Gen. 31:48).

In the second half of the $19^{\text {th }}$ and early $20^{\text {th }}$ centuries, Bem Street was mainly built up with Jewish buildings, in the same way as the other side streets of Horodots'ka Street. Tenementhouses in Horodots'ka Street were commissioned by Jewish owners in various styles. We should especially note building No. 117 (building of Mojżesz Fisher and Łazarus Sandler, architects Edward Skawiński and Henryk Orlean, 1911) featuring modernized Romanesque characteristics with elements of the Jewish style that emerged from the Moorish Revival style. In the second half of the $19^{\text {th }}$ century and the beginning of the $20^{\text {th }}$ century, at the time of its flourishing during the final decades of the Austrian Empire, the Jewish community in Lviv acquired numerous synagogues, prayer houses, mikvehs, schools, libraries, printing houses, editorial offices of newspapers and magazines, shelters, hospitals, a theatre providing performances in Yiddish (opened by J. B. Gimpel in 1889), banking and commercial buildings.

In Bernstein (today's Sholem Aleichem) Street, two public buildings were built in the NeoRenaissance and Neo-Baroque styles (with elements of the "Jewish Art Nouveau" in their interior design): the House of the Association of Lviv craftsmen Jad Haruzim ("Skillful Hand", architect M. Silberstein, 1896) and the House of the Board of the Jewish Religious Community - Qahal (1899, architects Antoni Rudolf Fleischl and Maurycy Gall).

In 1899-1902, the Jewish Hospital, founded by M. Lazarus, was built at 8 Rappoport Street (Fig. 3) - this is the only building that has survived in Lviv, being totally arranged in modernized motifs of Oriental architecture (Kravtsov, 2016b).

The hospital was built by Ivan Levynsky to a design by Kazimierz Mokłowski, with avant-corps, decorated horizontal bands of yellow and red bricks, openwork balustrades of attics with dentils, and a large bulbous dome, covered with tiles of four colors. Combined Moorish and Jewish motifs dominated in the bright paintings on the walls of the entrance passage, created by the Fleck brothers. The stylistics of the hospital was influenced by the architecture of the Reformer synagogue in Chernivtsi, built by Julian Zachariewicz in 1873-1877. As Zachariewicz himself noted in an article in the Viennese architectural journal Allgemeine Bauzeitung, he designed the location of the altar, Aron-Kodesch, according to the principles of Judaism. The exterior of the shrine was also meant to answer the purpose. "It was necessary for this building to look at least like a Christian church. The Moorish style is best suited for this, which is an expression of the feelings and spirit of the Moses religion", the architect emphasized (Zachariewicz, 1882).

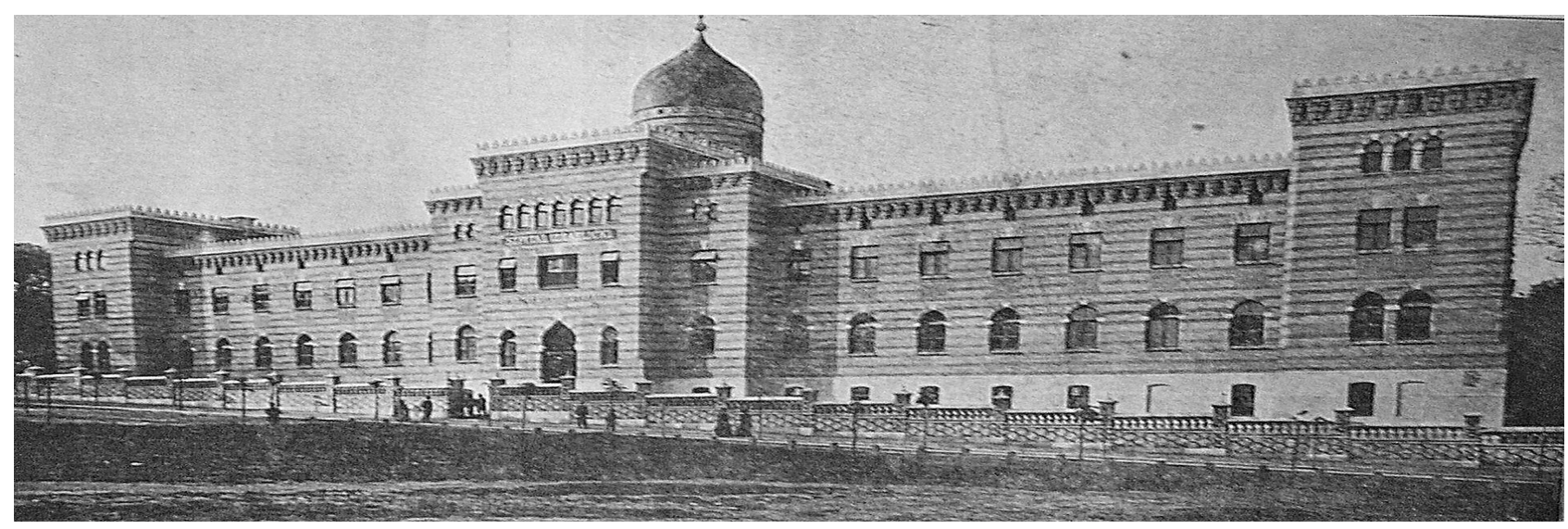

Figure 3. The Jewish Hospital. 1899-1902. Photo by Marek Münz, 1904, from Nowości ilustrowane, 8 (1904), p. 4 
The author of the Jewish hospital, Kazimierz Mokłowski, developed the theory of the new binational Polish-Ukrainian "Carpathian" style in his book "Folk Art in Poland" (1903). There he also explored the Galician wooden and nine-bay masonry synagogues of the $17^{\text {th }}-18^{\text {th }}$ century but did not see the possibility of creating a new Jewish national style based on their study.

These construction activities accompanied the beginning of the Jewish National Revival. Jewish construction in Lviv, throughout 1860-1914, took place within the framework of the economic, social, political, and specifically the public life of the city. Since 1869, when the Shomer Israel (Israel's Guardian) Association emerged, together with its Der Israelit weekly publication, assimilation tendencies among the Lviv Jews escalated, at first following a pro-German cultural orientation, and then a pro-Polish one, after the creation of the Agudas Achim (Association of Brothers) Society in 1883. At the same time, in 1880-1890s, Palestinophil and Zionist organizations were established, initiated in particular by writer and sculptor Alfred Nossig (Mendelsohn, 1971); a socialist movement was initiated by Herman Diamand. Lviv became a major center of Jewish education, book printing, scientific thought, literature, and art.

3. The emergence of new forms: Art Nouveau and the search for a new Jewish style

Religious and public buildings were of particular importance in the process of the emergence of new forms in Jewish architecture in Lviv in 1897-1918.

At the turn of the $19^{\text {th }}-20^{\text {th }}$ centuries in Lviv, as well as throughout Europe, one of the most important components of the artistic process was the study of the national heritage, folk art and the desire of art theorists and artists to create on this basis a new, original style inherent in each nation (Bowe, 1993). Polish and Ukrainian architects and artists of Lviv have successfully carried out such attempts since 1880 (Biryulov, 2001). In the Jewish environment of Lviv, similar actions (in particular, those associated with exhibiting a collection of Jewish art monuments at the General Regional Exhibition of 1894) had an obvious ideological and political aspect. The birth and spread of the ideas of Zionism (Mendelsohn, 1971; Wierzbieniec, 2005), "oriental exclusivity" in Lviv found a response among artists and architects who strove to create an original Jewish style. Many of the Zionists in Lviv proclaimed their Oriental separateness with pride. There was a "Semitic" stream in Zionism, whose chief ideological spokesman was Martin Buber, who came from a famous Lviv family.

The Moorish-Revival architectural style matched well with the Zionist ideology. From the 1870s to the end of the 19th century, many synagogues were built in this style in the USA, Great Britain,
Italy, Germany, Austria-Hungary (Klein, 2006; Kravtsov, 2016a; Wischnitzer, 1964). The ideals of Orientalist Zionism and of Moorish-Revival style synagogue architecture were joined in the work of Viennese architect Wilhelm Stiassny (Jarassé, 2001; Kravtsov, 2016a; Krinsky, 1985;), who was very famous in Galicia (in particular, in 1895 he built the Tempel synagogue in Stanislawów (now IvanoFrankivsk; the synagogue has not survived). His Jerusalem or "Jubilee" synagogue in Prague (1906) was already the work of a new Jewish national style, in the synthesis of Art Nouveau and NeoMoorish direction. Contemporaries and followers of Stiassny in Austria-Hungary, e.g. Lipót Baumhorn and younger Viennese architects also successfully worked in this direction, including creating secular buildings (Prokop, 2016).

At the turn of the $19^{\text {th }}$ and $20^{\text {th }}$ centuries, the architects of Lviv's synagogues retained the traditional two-level structure with a prayer room and a gallery, as well as an accent on Renaissance, Baroque, and Moorish forms. At the same time, attempts to shape the new Jewish artistic style as a branch of national romantic versions of Lviv Secession (Biryulov, 1999) were undertaken against that backdrop.

Julian Zachariewicz made his first attempt to create an architectural ensemble in the spirit of the "new Jewish style" in Lviv in 1894-1896 in his reconstruction projectfor the Progressive synagogue (Temple) in Rybny (Old Market) Square (Kravtsov, 2008). The idea of rebuilding the synagogue put forward by Zachariewicz was based on the concept of architect Charles Chipiez and archaeologist Georges Perrot. They proposed a combination of Assyrian, Phoenician, and Egyptian styles as a synthetic style of the Temple (Jarassé, 2001).

To get insight into Jewish ornamentation, in 1895 Zachariewicz collected traditional papercuts (migzarot), and in 1896 made sketches of the landscape of ancient Jerusalem for The Crucifixion panorama by Jan Styka, based on the study of ancient Jewish architecture.

After 1905, the acclaimed Józef Awin (18831942) was considered as the leading theoretician and architect of the Jewish version of Lviv Secession and "Post-Historicism". At first, he was influenced by Art Nouveau in its German version (Jugendstil) but quickly began to form his own artistic worldview. As the basis of the new style, Awin announced taking on board the traditions of the ancient Eastern Galicia's Jewish art, in particular, the architecture and decoration of the Galician wooden and nine-bay masonry synagogues of the $17^{\text {th }}-18^{\text {th }}$ centuries. Modern art history confirms that these old synagogues of the Polish-Lithuanian Commonwealth were an original stylistic phenomenon and deserved to become 
the basis for creating a new Jewish style (Krinsky, 1985; Piechotka and Piechotka, 2004; Wischnitzer, 1964). Awin took courageous steps to create a new architectural style based on an interpretation of the ancient Jewish and Near East art monuments. Awin expressed his views of the tasks faced by the new Jewish art in his articles "About our aesthetic culture" (1910), "About the style and character in architecture" (1911), and "About Herman Struck" (1913) (Kravtsov, 2010). The theoretical support for this search was subsequently provided by artist and art critic Oskar Aleksandrowicz.

Among Awin's buildings, the Jewish students' house stands out, i.e. the Academic House at 28 Saint Teresa Street (today's Metropolitan Angelovych Street), designed in conjunction with A. Zachariewicz in 1908-1909. An even, flat façade in the geometric Art Nouveau style, with its only décor being stucco with a plaited motif and a frieze depicting the Star of David, accommodated the interiors (main conference room, parlors, dining room, library, etc.), which are now missing. In their embellishment - wall panels, furniture, lamps, paintings, and stained glass - one of the first attempts to consistently implement the foundations of the new Jewish style was made. "The building possesses a somewhat unusual style: an attempt to stylize old Jewish motifs sits well with the features of Secession", noted one of the first visitors to the Academic House that was opened on 10 October 1909 (Żydowski dom akademicki, 1909).

In other works by Awin of that period reconstruction projects for the synagogue at the Old Cemetery in Lviv (1909), and projects that were never accomplished: a competition design of the Herzliya Hebrew Gymnasium in Jaffa (now in Tel Aviv, 1908) (Awin, 1910), a project of a synagogue in a Polish town (1909), tombstone designs, and the Jewish House in Drohobych (1908-1914) (Bunikiewicz, 1910; Ornamentyka żydowska na wystawie wiosennej, 1914) — neat geometricity and rational planning were combined with the stylization of old Jewish manuscripts, textile, matzevot (tombstones), and ritual metal items (menorahs, etc.).

These ideas became even more pronounced in the tombstones that were created in 1925-1930 at the New Jewish Cemetery in Lviv (those of banker Samuel Horowitz, Head of the Galician Zionists Gerszon Zipper, Editor-in-Chief of Jewish magazines AbrahamKorkis, journalistMojżeszFrostig,journalist and President of the Galician Zionists Leon Reich), and also in the interior design of the Lviv branch of the B'nai B'rith Society (1927) (Biryulov, 2019).

Architects Henryk Hersch Salwer, Bruno Bauer, Ferdynand (Feiwel) Kassler, Leopold Reiss, and Albert (Aba) Kornblüth introduced the transformed motifs of old Jewish ornamentation into their works. Using high three-level attics, Artur Schleyen rebuilt the Hasidic Synagogue in 1904 at Bożnicza (today's Sans'ka) Street. The building acquired the characteristics of modernized Late Renaissance and Mannerism, i.e. typical Lviv patterns of the late $16^{\text {th }}$ and first decades of the $17^{\text {th }}$ century.

The façade of the "Col Rina ve-Yeshua" ("Shouts of Joy and Salvation" — an allusion to Song of Songs, 118:15) Synagogue, also known as "Express", at 49 Źródlana (Dzherel'na) Street by A. Kornblüth attracted attention with an engaging blend of Oriental Secession themes in the shapes and decorations of the portal, windows, attics with numerous Jewish symbols, all together creating an integral arrangement, becoming one of the first distinctive works of Jewish Art Nouveau (State Archives of the Lviv Region, Collection 2, Register 1, File 3127, pp. 2, 4-11, 21-27) (Fig. 4).

In 1911-1912, the Korte Shul Synagogue at 109-111 Żółkiewska (B. Khmelnytskyi) Street, belonging to the "Gomel Chesed" ("Good Deeds") Society, was fundamentally rebuilt in the spirit of Jewish Art Nouveau, with a striking stylization of oriental motifs to a design by architect Bruno Bauer (the construction was supervised by A. Schleyen). The synagogue belonging to the "Beth-Lechem" ("Bread House") Society at 8 Starozakonna (Mstyslav Udatnyi) Street occupied the first two floors of the house built in 1912. In search of a new distinctive Jewish style close to Art Nouveau, architect Jakub Scheller created a remarkable design for the main façade, combining Moorish Revival motifs with the Jewish symbolism. The façade was lavishly decorated, with dripstone of exquisite and finely detailed configurations, and with double dormers on the pediment, recreating the outlines of the Tablets of Stone (State Archives of the Lviv Region, Collection 2, Register 1, File 725; Registry 2, File 3827) (Fig. 5).

At the same time, i.e. in the early $20^{\text {th }}$ century, synagogues appeared in different European countries, similar to the Prague Jubilee Synagogue of Stiassny, with an Art Nouveau interpretation of oriental or local traditional architecture, with characteristic ideological symbols in picturesque decoration. These were, e.g. the synagogues in Subotica (1902, architects M. Komor and D. Jakab), Malmö (1903, architect John Smedberg), the "Friedberger Anlage" synagogue in Frankfurt am Main (1904-1907; it has not survived), the Döbling Synagogue in Vienna (1907, Julius Wohlmuth), the Bournemouth Hebrew Congregation (1911), the Old Synagogue in Essen (1913, architect Edmund Körner), Kazinczy Street Synagogue in Budapest (1913, Sándor and Béla Löffler).

Awin and other Jewish architects of Lviv were obviously aware of the search for a new national style 
in the early $20^{\text {th }}$ century in Palestine. Expressing a romanticist tendency and the ideas of Art Nouveau style, the architects identified the "Oriental", especially the Palestinian vernacular culture, as a repository of the authentic but lost Hebraic identity. The Herzliya Hebrew Gymnasium in Jaffa (now in Tel Aviv, 1909, designed by Joseph Barsky) and the Technion - the Israel Institute of Technology in Haifa (architect Alexander Baerwald, 19101924) - are some of the brightest examples of the Palestinian version of Art Nouveau, which required the creation of a national style with an appeal to regional traditions (Harlap, 1982, 44; Sakr, 1996).

Before the outbreak of the World War I, Lviv architects worked mainly in line with this search for a new Jewish style.

In 1912-1913, the "Jankel Glanzer Schul" Hasidic synagogue at 3 Vuhil'na Street underwent a complete reconstruction. The architect, Włodzimierz Podhorodecki, altered the façades and the space of the prayer room, conforming to the Baroque style modernized in the spirit of Art Nouveau. F. Kassler tried to use the elaborate motifs of old Jewish art from the unrealized project of the Jewish People's House in Lviv (1914).

The pre-burial house "Beth Tahara" ("House of Purification") at the New Jewish Cemetery in Lviv (1911-1913, demolished in 1942) presented a striking ensemble of Jewish Secession. The style of the building constructed by M. Ulam to a design by R. Feliński and J. Grodyński (Budowle wykonane w dziesięcioleciu 1903-1913 przez firmę: Michał Ulam architekt-budowniczy, 1913; Filasiewicz,

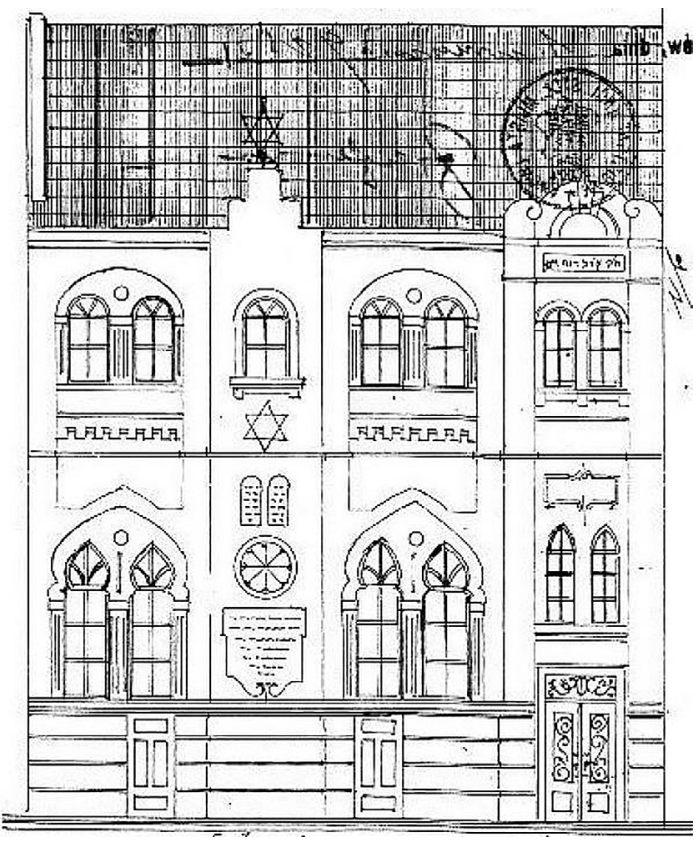

Figure 4. Façade of the "Col Rina ve-Yeshua" ("Shouts of Joy and Salvation") Synagogue. 1905. State Archives of the Lviv Region
1914) combined the trends of Neoclassicism and modernized Romanesque style, with the influence of Secession works by Otto Wagner (e.g. the Church of St. Leopold Kirche am Steinhof), and focus on the old Jewish architecture and ornamentation (Fig. 6).

On the façade, the motifs of Jewish ornamentation were noticeable in the decoration of inter-window half-columns. Inside, the walls of the room approximately $30 \mathrm{~m}$ high, covering a space of 600 sq. m, were abundant in frescoes and stainedglass windows by Feliks Wygrzywalski. In these, the artist employed compositional and decorative techniques of Art Nouveau, floral and geometric ornaments, and the re-evaluation of the motifs used in the decoration of synagogues in the $17^{\text {th }}$ and $18^{\text {th }}$ centuries (Jüdische Interessante Blatt, 1913, 1914).

A new house of the Jewish religious commune was erected in 1912-1913 at 27 Blacharska (I. Fedorov) Street to a design by Leopold Reiss and Artur Schleyen. The architects used stylized Renaissance motifs in the arrangement of the main façade. Pilasters with "diamond" rustication, together with the entrance portal and the attic, made the appearance of the new tenement house similar to that of the Jewish architecture of Lviv in the $16^{\text {th }}$ and $17^{\text {th }}$ centuries. Another appeal to the local Renaissance could be seen in the large threelevel stepped attic of the Academic House (Jewish Student's House) of the Jakob and Laura Herman Foundation at 7 Królewska (today's Y. Slipyi) Street (architect Adolf Piller, 1910-1911) (State Archives of the Lviv Region, Collection 2, Registry 1, File 5522, pp. 9-18).

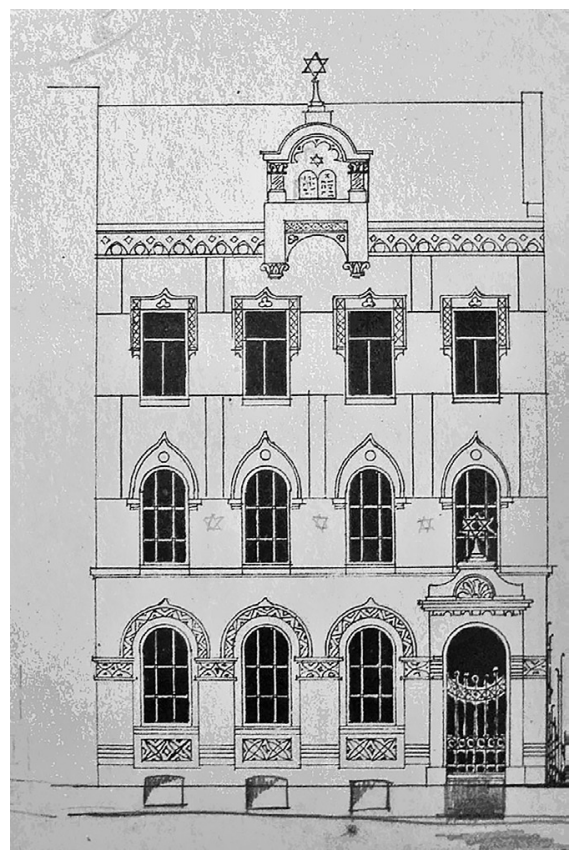

Figure 5. Façade of the synagogue belonging to the "BethLechem" ("Bread House") Society. 1912. State Archives of the Lviv Region 


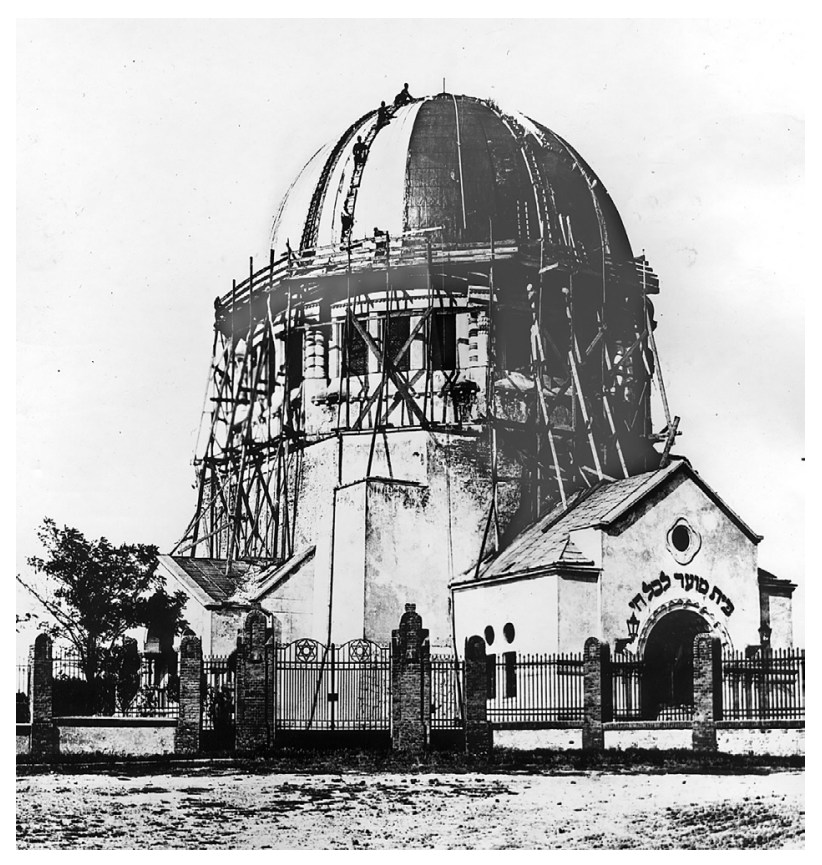

Figure 6. "Beth Tahara" ("House of Purification") pre-burial house at the New Jewish cemetery. 1911-1913. Photo of 1913. Lviv Historical Museum

We can also mention other examples of attempts to implement the idea of Jewish national identity in Lviv's residential architecture of the early $20^{\text {th }}$ century.

The tenement house of Isaac Hersz Sandel, built by Salomon Riemer in 1906-1907 at 5 Rejtan (Kurbas) Street, boasts a façade entirely covered with a decorative "carpet" of majolica tiles with an Art Nouveau stylization of Moorish Oriental motifs (manufactured at the workshop run by brothers Jacob and Maurycy Mund) (Fig. 7).

Another (apart from the house at Sienkiewicz Street) building making up the property of Jakub Seinwell Reiss, built in the "Rational" Secession style, to a design by Leopold Reiss at 4 Obertyńska (Zarytski) Street in 1909-1910, was decorated with a unique stained-glass composition on the staircase with traditional Jewish art motifs.

The building of Abraham Kinzler and Jan Marek, referred to as the "House of Winemakers", was erected in 1912-1913 at 49 Pekars'ka Street to a design by architect Walery Szulman in the "Rational" Secession style (State Archives of the Lviv Region, Collection 2, Registry 2, File 2315). The sculptor, presumably Franciszek Tomasz Biernat, referred to the symbols of the Old Testament and Palestine, using them as bas-reliefs depicting a grape harvest a theme widely used in the visual propaganda by Galician Zionists. The stained-glass windows of the staircase, with images of vines, are similar to the sculptural leitmotif.

The tenement house of Mojżesz Rohatyn at 12 Third of May (Sichovykh Striltsiv) Street, built

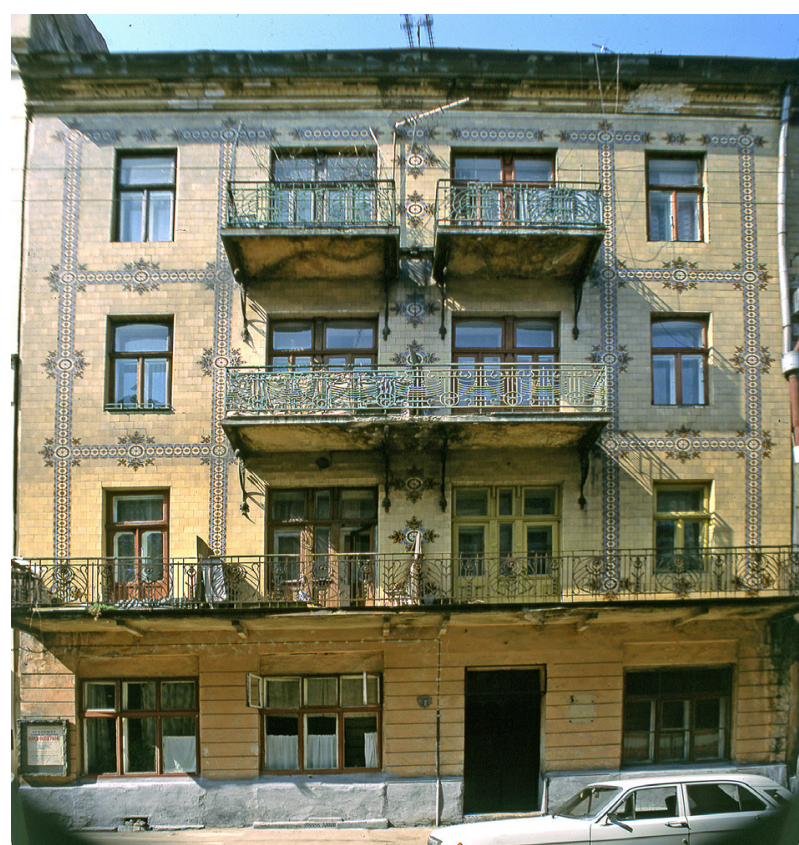

Figure 7. Tenement house of Isaac Hersz Sandel at 5 Kurbas Street. 1906-1907.

Photo: Ilia Levin, 2010

by R. Feliński in 1912-1913, features a NeoRomantic mood, with freely "flowing" clear-cut shapes. The façade and interiors acquired details borrowed from Oriental art, in addition to the motifs of the Middle Ages and Renaissance. In particular, the portal half-columns and inter-window columns featured carved Moorish and Jewish designs.

The intensive and brilliant development of Jewish architecture in Lviv came to a halt at the beginning of the World War II and the tragedy of the Holocaust.

\section{Conclusions}

The period from 1848 up to 1918 saw the exceptionally intensive interpretation of the patterns of specific regional art and folk art in architecture and related arts. In the second half of the $19^{\text {th }}$ century, the Jewish architecture of Lviv was characterized by the development of transformed Moorish style and other modernized Oriental motifs. At the same time, on that basis, the first attempts were undertaken to shape a unique Jewish artistic style, especially during the Art Nouveau period. The stylistic design strategy of the 1900-1910s was aimed at shaping Jewish cultural identity by creatively applying the principles of traditional Eastern (predominantly Moorish) architecture and the local Renaissance and Mannerist architecture of Galicia, without simply copying their elements and forms. The program acceptance of the new style suggested bringing into play the traditions of the old Jewish art of Eastern Galicia, including the architecture and decoration of synagogues of the $17^{\text {th }}-18^{\text {th }}$ centuries. Underlying the phenomenon 
of Lviv's Jewish architecture is the employment of Western European influences, combined with the rich local cultural experience. During and after the World War II, many landmarks of Jewish architecture were irretrievably damaged or destroyed. Nevertheless, Lviv still boasts an enormous number of valuable artifacts that are landmarks of Jewish culture. This legacy requires care, conservation, and a sound scientific description. 


\section{References}

\section{Unpublished Sources}

State Archives of Lviv Region, collection 2: Architectural matters, archives of the former municipal construction department of the City Council in Lviv: Register 1, files: 313, pp. 22, 36-42, 96-98, 122-123, 144-155; 725; 3018, p. 29; 3127, pp. 2, 4-11, 21-27; 5522, pp. 9-18; 5524; 5526, pp. 3-15. Register 2, files: 997, pp. 3, 16, 25, 33; 2315; 3827. Register 3, file 1479 , pp. 3, 4, 79.

\section{Published Sources}

Abel, C. (1997). Architecture and identity: towards a global eco-culture. Oxford: Architectural Press, 245 p.

Aleksandrowicz-Pędich, L. and Pakier, M. (eds.) (2012). Reconstructing Jewish identity in pre-and post-Holocaust literature and culture. Frankfurt am Main: Peter Lang, $182 \mathrm{p}$.

Awin, J. (1910). Projekt zu einem Hebraischem Gymnasium in Jaffa, Palästina. August 1908. In: Reich, L. (ed.) Almanach żydowski. Lwów: Drukarnia Udziałowa.

Bedoire, F. (2004). The Jewish contribution to modern architecture 1830-1930. Stockholm: KTAV Publishing House. 518 p.

Biryulov, Yu. (1999). Art Nouveau in Lvov. In: Krakowski, P. and Purchla, J. (eds.) Art around 1900 in Central Europe: art centres and provinces. International Conference, 20-24 October 1994. Cracow: International Cultural Centre, pp. $113-128$.

Biryulov, Yu. (2001). In search of "vernacular styles" in the Lvov milieu of the late $19^{\text {th }}$ and early $20^{\text {th }}$ centuries. In: Purchla, J. (ed.) Vernacular Art in Central Europe. International Conference, 1-5 October 1997. Cracow: International Cultural Centre, pp. 269-281.

Biryulov, Yu. (2019). Jewish sculptors in Lviv, 1919-1941. In: From Ausgleich to the Holocaust: Ukrainian and Jewish Artists of Lemberg/Lwów/Lviv. Weimar: Grünberg Verlag, pp. 150-163.

Bowe, N. G. (1993). Art and the national dream: search for vernacular expression in turn-of-the-century design. Blackrock: Irish Academic Press, 213 p.

Budowle wykonane w dziesięcioleciu 1903-1913 przez firmę: Michał Ulam architekt-budowniczy (1913). Buildings made in the decade 1903-1913 by Michał Ulam architect-builder. Lwów, pp. 121, 123-125.

Bunikiewicz, W. (1910). Powszechna wystawa sztuki polskiej. Architektura (General Exhibition of Polish Art. Architecture). Wiek nowy, 2766, September 27, pp. 2-3.

Buszko, J. (1999). The consequences of Galician autonomy after 1867. Polin 12: Focusing on Galicia, pp. 86-99.

Coenen Snyder, S. (2013). Building a public Judaism: synagogues and Jewish identity in nineteenth-century Europe. Cambridge: Harvard University Press, 360 p.

Filasiewicz, S. (1914). Budowle firmy Michała Ulama. Czasopismo Techniczne, 7, p. 87.

Harlap, A. (1982). New Israeli architecture. East Brunswick, NJ: Fairleigh Dickinson University Press, 355 p.

Holzer, J. (1999). Enlightenment, assimilation, and modern identity: The Jewish elite in Galicia. Polin 12: Focusing on Galicia, pp. 79-85.

Jarassé, D. (2001). Synagogues: architecture and Jewish identity. Paris: Vilo International, 285 p.

Jüdische Interessante Blatt (1913, 1914). 1913, No. 4, December 26, p. 2; 1914, No. 21, June 19, pp. 3-4.

Kalmar, I. D. (2001). Moorish styles: orientalism, the Jews, and synagogue architecture. Jewish Social Studies: History, Culture, Society, 7 (3), pp. 68-100.

Klein, R. (2005-2007). Secession: un gout juif? - Art Nouveau buildings and the Jews in some Habsburg lands. Jewish Studies at the CEU, Vol. V, pp. 91-124. Budapest.

Klein, R. (2006). Oriental-style synagogues in Austria-Hungary: Philosophy and historical significance. Ars Judaica, 2 (1), pp. 17-134.

Kravtsov, S. R. (2008). Reconstruction of the temple by Charles Chipiez and its applications in architecture. Ars Judaica, 4, pp. 25-42.

Kravtsov, S. R. (2010). Jozef Awin on Jewish art and architecture. In: Malinowski, J., Piqtkowska, R. and Sztyma-Knasiecka, T. (eds.) Jewish artists and Central-Eastern Europe: art centers, identity, heritage from the $19^{\text {th }}$ century to the Second World War. Warsaw: DIG, pp. 131-144. 
Kravtsov, S. R. (2016a). Architecture of "new synagogues" in Central-Eastern Europe. In: Brämer, A., Przystawik, M. and Thies, H. H. (eds.) Reform Judaism and Architecture. Petersberg: Michael Imhof Verlag; Hamburg: Institut für die Geschichte der deutschen Juden, pp. 47-78.

Kravtsov, S. R. (2016b). The Israelite hospital in Lemberg/Lwów/Lviv, 1898-1912. "Jewish" architecture by an "international" team. Jews and Slavs, 25, pp. 85-100.

Krinsky, C. H. (1985). Synagogues of Europe: architecture, history, meaning. Cambridge, MA: Massachusetts Institute of Technology, $457 \mathrm{p}$.

Lefaivre, L. and Tzonis, A. (2003). Critical regionalism. Architecture and identity in a globalized world. München: Prestel, $160 \mathrm{p}$.

Mendelsohn, E. (1971). From assimilation to Zionism in Lvov: the case of Alfred Nossig. Slavonic and East European Review, 49 (117), pp. 521-534.

Ornamentyka żydowska na wystawie wiosennej (1914). Jewish ornamentation at the spring exhibition. Korespondencja żydowska, 2, June 27, p. 3.

Piechotka, M. and Piechotka, K. (2004). Heaven's gate: wooden synagogues in the territory of the former Polish-Lithuanian Commonwealth. Warsaw: Institute of Art, Polish Academy of Sciences, $416 \mathrm{p}$.

Prokop, U. (2016). On the Jewish legacy in Viennese architecture: The contribution of Jewish architects to building in Vienna 1868-1938. Wien: Böhlau, 256 p.

Rabin, C. (1996). The national Idea and the revival of Hebrew. In: Reinharz, J. and Shapira, A. (eds.) Essential Papers on Zionism. New York and London: New York University Press, pp. 745-762.

Renowacja wielkiej synagogi przy ul. Żółkiewskiej (1925). Renovation of the Great Synagogue at Żółkiewska Street. Chwila, 2333, p. 7.

Sachs, A. and Van Voolen, E. (eds.) (2004). Jewish identity in contemporary architecture. München, Berlin, London, New York: Prestel, $176 \mathrm{p}$.

Sakr, Y. M. (1996). The subversive utopia: Louis Kahn and the question of the national Jewish style in Jerusalem. PhD Thesis in Architecture. Philadelphia, PA: University of Pennsylvania.

Shapira, E. (2016). Style and seduction: Jewish patrons, architecture, and design in Fin de Siècle Vienna. Waltham, MA: Brandeis University Press, $336 \mathrm{p}$.

Van Pelt, R. J. and Westfall, C. W. (1991). Architectural principles in the age of historicism. New Haven and London: Yale University Press, $417 \mathrm{p}$.

Watson, G. B. and Bentley, J. (2007). Identity by Design. Amsterdam: Elsevier, Architectural Press, 298 p.

Wierzbieniec, W. (2005). The processes of Jewish emancipation and assimilation in the multiethnic city of Lviv during the nineteenth and twentieth centuries. In: Harvard Ukrainian Studies, 24, pp. 223-250.

Wischnitzer, R. (1964). The architecture of the European synagogue. Philadelphia, PA: Jewish Publication Society of America, $312 \mathrm{p}$.

Zachariewicz, J. (1882). Israelitischer Tempel in Czernowitz. Allgemeine Bauzeitung, 47, pp. 48-49.

Żydowski dom akademicki (1909). (Jewish Academic House). Kurier Iwowski, 402, p. 3; Przegląd polityczny, społeczny i literacki, 233, p. 2. 